\title{
Correction to: Hydraulic insertions of cochlear implant electrode arrays into the human cadaver cochlea: preliminary findings
}

\author{
M. Geraldine Zuniga ${ }^{1} \cdot$ Thomas Lenarz $^{1} \cdot$ Thomas S. Rau $^{1}$
}

Published online: 3 September 2021

(c) The Author(s) 2021

\section{Correction to: European Archives of Oto-Rhino-Laryngology https://doi.org/10.1007/s00405-021-06979-z}

In the original version of this article, the author name M. Geraldine Zuniga was incorrectly written as M. Geraldine and the name is corrected in this article.

The original article was updated.

Open Access This article is licensed under a Creative Commons Attribution 4.0 International License, which permits use, sharing, adaptation, distribution and reproduction in any medium or format, as long as you give appropriate credit to the original author(s) and the source, provide a link to the Creative Commons licence, and indicate if changes were made. The images or other third party material in this article are included in the article's Creative Commons licence, unless indicated otherwise in a credit line to the material. If material is not included in the article's Creative Commons licence and your intended use is not permitted by statutory regulation or exceeds the permitted use, you will need to obtain permission directly from the copyright holder. To view a copy of this licence, visit http://creativecommons.org/licenses/by/4.0/.

Publisher's Note Springer Nature remains neutral with regard to jurisdictional claims in published maps and institutional affiliations.
The original article can be found online at https://doi.org/10.1007/ s00405-021-06979-z.

M. Geraldine Zuniga

zunigamanrique.maria@mh-hannover.de

1 Department of Otolaryngology and Cluster of Excellence Hearing4all, Hannover Medical School, Carl-Neuberg-Str. 1, 30625 Hannover, Germany 